\title{
Asuhan Keperawatan Jiwa Pada Ny.S Dengan Masalah Halusinasi Pendengaran
}

\author{
Ayu Sastiya \\ Ayusastiya8@gmail.com

\section{BAB 1 \\ PENDAHULUAN}

\subsection{Latar Belakang}

Skizofrenia merupakan reaksi psikotik yang berpengaruh terhadap area fungsi individu, termasuk dalam berpikir, berkomunikasi, menerima, menafsirkan kenyataan, merasakan dan menunjukkan emosi serta penyakit kronis yang ditandai dengan pikiran kacau, delusi, halusinasi, dan perilaku aneh. Skizofrenia biasanya muncul dalam masa remaja atau dewasa muda (sebelum usia 45 tahun). Seseorang dikatakan menderita skizofrenia apabila perjalanan penyakitnya sudah berlangsung lewat 6 bulan, sebelumnya di dahului oleh gejala awal di sebut sebagai fase prodromal yang di tandai dengan muncul nya gejala - gejala yang tidak lazim misalnya: pikiran tidak rasional, perasaan tidak wajar, berperilaku aneh, penarikan diri, pikiran kacau, merasa tidak mampu, berbicara tidak sesuai dan sebagainya (Pardede \& Laia, 2020).

Skizofrenia menimbulkan distorsi pikiran, distorsi persepsi, emosi, dan tingkah laku sehingga pasien dengan skizofrenia memiliki risiko lebih tinggi berperilaku agresif di mana perubahan perilaku secara dramatis terjadi dalam beberapa hari atau minggu. Hal inilah yang membuat perlu bantuan keluarga untuk merawat dan memberikan perhatian khusus pada pasien skizofrenia (Pardede \& Siregar, 2016). Fenomena gangguan jiwa pada saat ini mengalami peningkatan yang sangat signifikan, dan setiap tahun di berbagai belahan dunia jumlah penderita gangguan jiwa bertambah. Berdasarkan data dari 
(WHO, 2013) ada sekitar 450 juta orang di dunia yang mengalami gangguan jiwa. Berdasarkan hasil penelitian dari (Pardede, \& Hasibuan, 2019).

Prevalensi masalah kesehatan jiwa di Indonesia di Indonesia, estimasi jumlah penderita skizofrenia mencapai sekitar 400.000 orang atau sebanyak 1,7 per 1.000 penduduk Riskesdas 2013, sedangkan Riskesdas 2018 juga menyebutkan sebanyak 84,9\% pengidap skizofrenia/psikosis di Indonesia.

Halusinasi adalah suatu keadaan dimana seseorang mengalami perubahan dalam jumlah dan pola dari stimulus yang datang (diprakarsai) dari internal dan eksternal disertai dengan respon menurun atau dilebih-lebihkan atau kerusakan respon pada rangsangan ini (Hendarsyah, 2016). Klien dengan skizofrenia mengalami halusinasi, meskipun halusinasinya bervariasi tetapi sebagian besar klien skizofrenia di Rumah Sakit Jiwa mengalami halusinasi dengar diperkirakan 90\%.(Sutinah et al,2020). Survei awal dilakukan di Yayasan Pemenang Jiwa Sumatra dengan jumlah pasien 70 orang tetapi yang menjadi subjek di dalam pembuatan askep ini berjumlah 1 orang dengan pasien masah halusinasi pendengaran atas nama inisial Ny.S, penyebabnya Ny.S sebagai subjek di karenakan pasien belum bisa mengatasi emosinya selain minum obat.

Upaya yang dilakukan untuk menangani klien halusinasi adalah dengan memberikan tidakan keperawatan yaitu membantu pasien mengenali halusinasi, isi halusinasi, waktu terjadi halusinasi, frekuensi terjadinya halusinasi, situasi yang menyebabkan halusinasi muncul dan respon klien saat halusinasi muncul. Kemuadian dengan melatih klien mengontrol halusinasi dengan menggunakan strategi pelaksanaanya itu dengan cara menghardik halusinasi, bercakap-cakap dengan orang lain, melakukan aktivitas yang terjadwal dan menggunakan obat secara teratur (Halawa, 2015).Maka tujuan asuhan keperawatan yang akan di lakukan ialah untuk mengajarkan standar pelaksanaan masalah halusinasi pendengaran pada saat Ny.S mengalami halusinasinya. 


\subsection{Rumusan Masalah}

Berdasarkan masalah yang telah di paparkan pada latar belakang maka rumusan masalah dalam askep ini yaitu Asuhan keperawatan masalah halusinasi pendengaran Ny.S, di yaayasan pemenang jiwa.

\subsection{Tujuan}

\subsubsection{Tujuan Umum}

Mahasiswa mampu memberikan asuhan keperawatan secara holistik dan komprehensif kepada Ny.S dengan gangguan persepsi sensori : halusinasi pendengaran.

\subsubsection{Tujuan Khusus}

1. Mahasiswa mampu melakukan pengkajian pada Ny.S dengan gangguan persepsi sensori : halusinasi pendengaran.

2. Mahasiswa mampu menegakkan diagnosa keperawatan yang ada pada Ny.S dengan gangguan persepsi sensori : halusinasi pendengaran.

3. Mahasiswa menetapkan perencanaan keperawatan pada Ny.S dengan gangguan persepsi sensori : halusinasi pendengaran.

4. Mahasiswa melakukan implementasi keperawatan pada Ny.S dengan gangguan persepsi sensori : halusinasi pendengaran.

5. Mahasiswa mengevaluasi hasil asuhan keperawatan pada Ny.S dengan gangguan persepsi sensori : halusinasi pendengaran.

6. Mendokumentasikan asuhan keperawatan yang diberikan pada Ny.S dengan gangguan persepsi sensori : halusinasi pendengaran. 


\section{BAB 2 \\ TINJAUAN TEORI}

\subsection{Konsep Halusinasi}

\subsubsection{Pengertian}

Halusinasi adalah suatu keadaan dimana seseorang mengalami perubahan dalam jumlah dan pola dari stimulus yang datang (diprakarsai) dari internal dan eksternal disertai dengan respon menurun atau dilebih-lebihkan atau kerusakan respon pada rangsangan ini (Hendarsyah, 2016). Klien dengan skizofrenia mengalami halusinasi, meskipun halusinasinya bervariasi tetapi sebagian besar klien skizofrenia di Rumah Sakit Jiwa mengalami halusinasi dengar diperkirakan 90\%.(Sutinah et al,2020). Halusinasi pendengaran paling sering terjadi ketika klien mendengar suara-suara, Halusinasi pendengaran adalah mendengar suara atau kebisingan, paling sering suara orang. Suara berbentuk kebisingan yang kurang jelas sampai katakata yang jelas berbicara tentang klien, bahkan sampai pada percakapan lengkap antara dua orang yang mengalami halusinasi. Pikiran yang terdengar dimana klien mendengar perkataan bahwa klien disuruh untuk melakukan sesuatu kadang dapat membahayakan (azizah, 2016)

\subsubsection{Klasifikasi Halusinasi}

Menurut Yusuf et al (2015) klasifikasi halusinasi dibagi menjadi 5 yaitu :

\begin{tabular}{|c|c|c|c|}
\hline No & $\begin{array}{l}\text { Jenis } \\
\text { halusinasi }\end{array}$ & Data Objektif & Data Subjektif \\
\hline 1 & $\begin{array}{l}\text { Halusinasi } \\
\text { Pendengaran }\end{array}$ & $\begin{array}{l}\text { 1. Bicara atau } \\
\text { tertawa sendiri } \\
\text { tanpa lawan } \\
\text { bicara } \\
\text { 2. Marah-marah } \\
\text { tanpa sebab }\end{array}$ & $\begin{array}{l}\text { 1. Mendengar suara atau } \\
\text { kegaduhan } \\
\text { 2. Mendengar suara yang } \\
\text { mengajak bercakap- } \\
\text { cakap } \\
\text { 3. Mendengar suara yang }\end{array}$ \\
\hline
\end{tabular}




\begin{tabular}{|c|c|c|c|}
\hline & & $\begin{array}{l}\text { mencondongka } \\
\mathrm{n} \text { telinga ke } \\
\text { arah tertentu } \\
\text { 3. Menutup } \\
\text { telinga }\end{array}$ & $\begin{array}{l}\text { menyuruh melakukan } \\
\text { sesuatu yang berbahaya }\end{array}$ \\
\hline 2 & $\begin{array}{l}\text { Halusinasi } \\
\text { penglihatan }\end{array}$ & $\begin{array}{l}\text { 1. Menunjuk- } \\
\text { nunjuk ke arah } \\
\text { tertentu } \\
\text { 2. Ketakutan pada } \\
\text { objek yang } \\
\text { tidak jelas }\end{array}$ & $\begin{array}{l}\text { 1. Melihat bayangan, sinar, } \\
\text { bentuk geometris, } \\
\text { bentuk kartun, melihat } \\
\text { hantu atau monster }\end{array}$ \\
\hline 3 & $\begin{array}{l}\text { Halusinasi } \\
\text { penghindu }\end{array}$ & $\begin{array}{l}\text { 1. Menghindu } \\
\text { seperti sedang } \\
\text { membaui bau- } \\
\text { bauan tertentu } \\
\text { 2. Menutup } \\
\text { hidung }\end{array}$ & $\begin{array}{l}\text { 1. Membaui bau-bauan } \\
\text { seperti bau darah, urine, } \\
\text { feses, } \\
\text { 2. kadang-kadang bau itu } \\
\text { menyenangkan }\end{array}$ \\
\hline 4 & $\begin{array}{l}\text { Halusinasi } \\
\text { pengecepan }\end{array}$ & $\begin{array}{l}\text { 1. Sering meludah } \\
\text { 2. Muntah }\end{array}$ & $\begin{array}{l}\text { 1. Merasakan rasa seperti } \\
\text { darah, urine, feses }\end{array}$ \\
\hline 5 & $\begin{array}{l}\text { Halusinasi } \\
\text { perabaan }\end{array}$ & $\begin{array}{l}\text { Menggaruk-garuk } \\
\text { permukaan kulit }\end{array}$ & $\begin{array}{l}\text { 1. Mengatakan ada } \\
\text { serangga di permukaan } \\
\text { kulit } \\
\text { 2. Merasa seperti tersengat } \\
\text { listrik }\end{array}$ \\
\hline
\end{tabular}

\subsubsection{Tanda dan Gejala}

Tanda dan gejala halusinasi dinilai dari hasil observasi terhadap pasien serta ungkapan pasien menurut (Hafizudiin, 2021) :

1. Menyeringai atau tertawa yang tidak sesuai

2. Menggerakkan bibirnya tanpa menimbulkan suara

3. Gerakan mata cepat

4. Menutup telinga 
5. Respon verbal lambat atau diam

6. Diam dan dipenuhi oleh sesuatu yang mengasyikkan

7. Terlihat bicara sendiri

8. Menggerakkan bola mata dengan cepat

9. Bergerak seperti membuang atau mengambil sesuatu

10. Duduk terpaku, memandang sesuatu, tiba-tiba berlari ke ruangan lain

11. Disorientasi (waktu, tempat, orang)

12. Perubahan kemampuan dan memecahkan masalah

13. Perubahan perilaku dan pola komunikasi

14. Gelisah, ketakutan, ansietas

15. Peka rangsang

16. Melaporkan adanya halusinasi

\subsubsection{Etiologi}

Etiologi Faktor predisposisi klien halusinasi menurut Oktavia (2020).

1. Faktor predisposisi

a. Faktor perkembangan

Tugas perkembangan klien terganggu misalnya rendahnya kontrol dan kehangatan keluarga menyebabkan klien tidak mampu mandiri sejak kecil, mudah frustasi, hilang percaya diri.

b. Faktor sosiokultural

Seseorang yang merasa tidak diterima dilingkungan sejak bayi akan merasa disingkirkan, kesepian, dan tidak percaya pada lingkungan

c. Faktor biologis

Mempunyai pengaruh terhadap terjadinya gangguan jiwa. Adanya stress yang berlebihan dialami seseorang maka didalam tubuh akan dihasilkan suatu zat yang dapat bersifat halusinogen neurokimia. Akibat stress berkepanjangan menyebabkan teraktivasinya neurotransmitter otak.

d. Faktor psikologis 
Tipe kepribadian lemah dan tidak bertanggung jawab mudah terjerumus pada penyalahgunaan zat adikitif. Hal ini berpengaruh pada ketidakmampuan klien dalam mengambil keputusan yang tepat demi masa depannya, klien lebih memilih kesenangan sesaat dan lari dari alam nyata menuju alam khayal.

e. Faktor genetik dan pola asuh

Penelitian menunjukkan bahwa anak sehat yang diasuh oleh orang tua schizofrenia cenderung mengalami skizofrenia. Hasil studi menunjukkan bahwa faktor keluarga menunjukkan hubungan yang sangat berpengaruh pada penyakit ini.

\section{Faktor presipitasi}

Faktor presipitasi merupakan stimulus yang dipersepsikan oleh individu sebagai tantangan, ancaman, atau tuntutan yang memerlukan energi ekstra untuk menghadapinya. Seperti adanya rangsangan dari lingkungan, misalnya partisipasi klien dalam kelompok, terlalu lama tidak diajak komunikasi, objek yang ada di lingkungan dan juga suasana sepi atau terisolasi, sering menjadi pencetus terjadinya halusinasi. Hal tersebut dapat meningkatkan stress dan kecemasan yang merangsang tubuh mengeluarkan zat halusinogenik. Penyebab Halusinasi dapat dilihat dari lima dimensi yaitu :

a. Dimensi fisik

Halusinasi dapat ditimbulkan oleh beberapa kondisi fisik seperti kelelahan yang luar biasa, penggunaaan obat-obatan, demam hingga delirium, intoksikasi alkohol dan kesulitan untuk tidur dalam waktu yang lama.

\section{b. Dimensi Emosional}

Perasaan cemas yang berlebihan atas dasar problem yang tidak dapat diatasi merupakan penyebab halusinasi itu terjadi. Isi dari halusinasi dapat berupa perintah memaksa dan menakutkan. Klien 
tidak sanggup lagi menentang perintah tersebut hingga dengan kondisi tersebut klien berbuat sesuatu terhadap ketakutan tersebut.

c. Dimensi Intelektual

Dalam dimensi intelektual ini menerangkan bahwa individu dengan halusinasi akan memperlihatkan adanya penurunan fungsi ego. Pada awalnya halusinasi merupakan usaha dari ego sendiri untuk melawan impuls yang menekan, namun merupakan suatu hal yang menimbulkan kewaspadaan yang dapat mengambil seluruh perhatian klien dan tidak jarang akan mengontrol semua perilaku klien.

d. Dimensi Sosial

Klien mengalami interaksi sosial dalam fase awal dan comforting, klien meganggap bahwa hidup bersosialisasi di alam nyata sangat membahayakan. Klien asyik dengan Halusinasinya, seolah-olah ia merupakan tempat untuk memenuhi kebutuhan akan interaksi sosial, kontrol diri dan harga diri yang tidak didapatkan dakam dunia nyata.

e. Dimensi Spiritual

Secara sepiritual klien Halusinasi mulai dengan kehampaan hidup, rutinitas tidak bermakna, hilangnya aktifitas ibadah dan jarang berupaya secara sepiritual untuk menyucikan diri. Saat bangun tidur klien merasa hampa dan tidak jelas tujuan hidupnya. Individu sering memaki takdir tetapi lemah dalam upaya menjemput rezeki, menyalahkan lingkungan dan orang lain yang menyebabkan takdirnya memburuk. (Oktavia, 2020)

\subsubsection{Rentang Respon Neurobiologi}

Halusinasi merupakangangguan dari persepsi sensori, wahammerupakan gangguan pada isi pikiran. Keduanya merupakan gangguan darirespons neorobiologi. Oleh karenanya secara keseluruhan, rentang responshalusinasi mengikuti kaidah rentang respons neorobiologi Menurut Yusuf et al (2015) 


\begin{tabular}{|l|l|l|}
\hline Pikiran logis & Kadang pikiran & Gangguan \\
Persepsi akurat & terganggu & pikir/delusi \\
Emosi konsisten & Ilusi & Halusinasi \\
dengan pengalaman & Emosi & Tidak mampu mengalami \\
Perilaku sesuai & berlebihan/kurang & emosi \\
Hubungan social & Perilaku yang tidak bisa & Perilaku tidak terorganisir \\
positif & Menarik diri & Isolasi social \\
& & \\
\hline
\end{tabular}

\section{Respon Adaptif}

Respon adaptif adalah respon yang dapat diterima norma-norma sosial budaya yang berlaku. Dengan kata lain individu tersebut dalam batas normal jika menghadapi suatu masalah akan dapat memecahkan masalah tersebut, respon adaptif:

a. Pikiran logis adalah pandangan yang mengarah pada kenyataan.

b. Persepsi akurat adalah pandangan yang tepat pada kenyataan.

c. Emosi konsisten dengan pengalaman yaitu perasaan yang timbul dari pengalaman.

d. Perilaku sosial adalah sikap dan tingkah laku yang masih dalam batas kewajaran.

e. Hubungan sosial adalah proses suatu interaksi dengan orang lain dan lingkungan.

\section{Respon Psikososial}

Respon psikosial meliputi:

a. Proses pikir terganggu adalah proses pikir yang menimbulkan gangguan.

b. Ilusi adalah interpretasi atau penilaian yang salah tentang penerapan yang benar-benar terjadi (objek nyata) karena rangsangan panca indera. 
c. Emosi berlebihan atau berkurang.

d. Perilaku tidak biasa adalah sikap dan tingkah laku yang melebihi batas kewajaran.

e. Menarik diri adalah percobaan untuk menghindar interaksi dengan orang lain.

\section{Respon Maladaptif}

Respon maladaptif adalah respon individu dalam menyelesaikan masalah yang menyimpang dari norma-norma sosial budaya dan lingkungan, adapun respon maladaptif meliputi:

a. Kelainan pikiran adalah keyakianan yang secara kokoh dipertahankan walaupun tidak diyakini oleh orang lain dan bertetangan dengan kenyataan sosial.

b. Halusinasi merupakan persepsi sensori yang salah atau persepsi eksternal yang tidak realita atau tidak ada.

c. Kerusakan proses emosi adalah perubahan sesuatu yang timbul dari hati.

d. Perilaku tidak terorganisir merupakan suatu yang tidak teratur.

e. Isolasi sosial adalah kondisi kesendirian yang dialami oleh individu dan diterima sebagai ketentuan oleh orang lain dan sebagai suatu kecelakaan yang negatif mengancam.(Yusuf et al, 2015)

\subsubsection{Fase Halusinasi}

Menurut Yusuf et al (2015), karakteristik dan perilaku pasien halusinasi mengalami beberapa fase berikut :

\begin{tabular}{|l|lr|l|}
\hline Level & \multicolumn{2}{|l|}{ Karakteristik pasien } & Prilaku pasien \\
\hline .TAHAP 1 & $\bullet$ Mengalami ansitas & $\bullet$ Tersenyum \\
Memberi rasa nyaman & kesepian, rasa & tertawa sendiri \\
tingkat ansietas & bersalah, dan & $\bullet$ Menggerakan bibir \\
sedang. Secara umum & ketakutan . & tanpa suara \\
halusinasi merupakan & $\bullet$ & Mencoba berfokus & - Penggerakan mata \\
suatu kesenangan & \multicolumn{2}{|c|}{ pada pikiran yang } & yang cepat \\
\hline
\end{tabular}




\begin{tabular}{|c|c|c|}
\hline & $\begin{array}{l}\text { dapat menghilangkan } \\
\text { ansietas } \\
\text { - } \text { Pikiran dan } \\
\text { pengalaman } \\
\text { masih ada } \\
\text { kontrol dalam } \\
\text { (jika kesadaran } \\
\text { dikontrol) }\end{array}$ & $\begin{array}{l}\text { - Respon verbal } \\
\text { yang lambat } \\
\text { - Diam dan } \\
\text { berkonsentrasi }\end{array}$ \\
\hline $\begin{array}{lr}\text { TAHAP II } & \\
\text { Menyalahkan } & \text { tingkat } \\
\text { kecemasan } & \text { berat } \\
\text { secara } & \text { umum } \\
\text { halusinasi } & \\
\text { menyebabkan } & \text { rasa } \\
\text { antipati } & \end{array}$ & 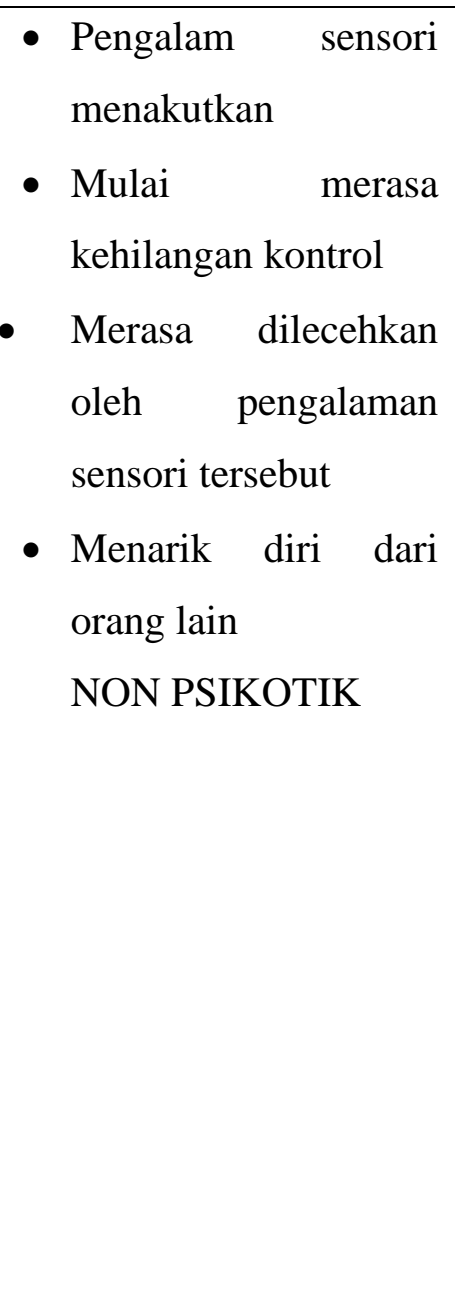 & $\begin{array}{l}\text { - Peningkatan } \\
\text { sistem saraf otak, } \\
\text { tanda-tanda } \\
\text { ansietas, seperti } \\
\text { peningkatan } \\
\text { denyut jantung, } \\
\text { pernafasan, dan } \\
\text { tekanan darah. } \\
\text { - Rentang perhatian } \\
\text { menyempit. } \\
\text { - Konsentrasi dan } \\
\text { pengalaman } \\
\text { sensori. } \\
\text { Kehilangan } \\
\text { kemampuan } \\
\text { membedakan } \\
\text { halusiasi dan } \\
\text { realita }\end{array}$ \\
\hline $\begin{array}{lr}\text { TAHAP III } \\
\text { Mengontrol tingkat } \\
\text { kecemasan } \\
\text { pengalaman } \\
\text { tidak dapat di tolak } \\
\text { lagi }\end{array}$ & $\begin{array}{l}\text { - Pasien menyerah dan } \\
\text { menerima } \\
\text { pengalaman } \\
\text { sensorinya } \\
\text { - Isi halunasi menjadi } \\
\text { atraktif }\end{array}$ & $\begin{array}{l}\text { - Perintah halusinasi } \\
\text { ditaati } \\
\text { - Sulit berhubungan } \\
\text { dengan orang lain } \\
\text { - Rentang perhatian } \\
\text { hanaya beberapa }\end{array}$ \\
\hline
\end{tabular}




\begin{tabular}{|c|c|c|}
\hline & 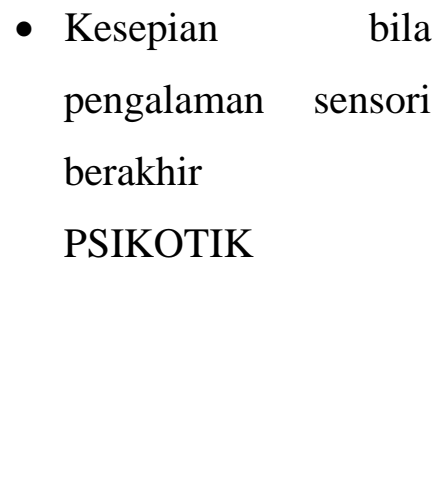 & $\begin{array}{l}\text { detik atau menit. } \\
\text { - Gejala fisika } \\
\text { ansietas,berat } \\
\text { berkeringat, } \\
\text { tremor, dan tidak } \\
\text { mampu mengikuti } \\
\text { perintah }\end{array}$ \\
\hline $\begin{array}{l}\text { TAHAP IV } \\
\text { Menguasai tingkat } \\
\text { kecemasan panik }\end{array}$ & 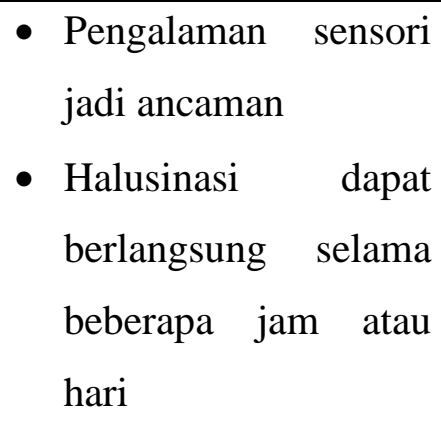 & $\begin{array}{l}\text { - Prilaku panik } \\
\text { - Potensial tinggi } \\
\text { untuk bunuh diri } \\
\text { atau membunuh } \\
\text { - Tinfdakan } \\
\text { kekerasan. }\end{array}$ \\
\hline
\end{tabular}

\subsubsection{Komplikasi}

Halusinasi dapat menjadi suatu alasan mengapa klien melakukan tindakan perilaku kekerasan karena suara-suara yang memberinya perintah sehingga rentan melakukan perilaku yang tidak adaptif. Perilaku kekerasan yang timbul pada klien skizofrenia diawali dengan adanya perasaan tidak berharga, takut dan ditolak oleh lingkungan sehingga individu akan menyingkir dari hubungan interpersonal dengan orang lain (Keliat, 2014). Komplikasi yang dapat terjadi pada klien dengan masalah utama gangguan sensori persepsi: halusinasi, antara lain: resiko prilaku kekerasan, harga diri rendah dan isolasi sosial.

\subsection{Konsep Dasar Asuhan Keperawatan}

\subsubsection{Pengkajian Keperawatan}

Menurut (Yusuf et al,2015), Bahwa faktor-faktor terjadinya halusinasi meliputi: 


\section{Faktor Predisposisi}

a. Faktor perkembangan

Hambatan perkembangan akan mengganggu hubungan interpersonal yang dapat meningkatkan stres dan ansietas yang dapat berakhir dengan gangguan persepsi. Pasien mungkin menekan perasaannya sehingga pematangan fungsi intelektual dan emosi tidak efektif.

b. Faktor sosial budaya

Berbagai faktor di masyarakat yang membuat seseorang merasa disingkirkan atau kesepian, selanjutnya tidak dapat diatasi sehingga timbul akibat berat seperti delusi dan halusinasi.

c. Faktor psikologis

Hubungan interpersonal yang tidak harmonis, serta peran ganda atau peran yang bertentangan dapat menimbulkan ansietas berat terakhir dengan pengingkaran terhadap kenyataan, sehingga terjadi halusinasi.

d. Faktor biologis

Struktur otak yang abnormal ditemukan pada pasien gangguan orientasi realitas, serta dapat ditemukan atropik otak, pembesaran ventikal, perubahan besar, serta bentuk sel kortikal dan limbik.

e. Faktor genetic

Gangguan orientasi realitas termasuk halusinasi umumnya ditemukan pada pasien skizofrenia. Skizofrenia ditemukan cukup tinggi pada keluarga yang salah satu anggota keluarganya mengalami skizofrenia, serta akan lebih tinggi jika kedua orang tua skizofrenia.

\subsubsection{Diagnosa Keperawatan}

Menurut NANDA 2015-2017 yakni gangguan persepsi. Dengan faktor berhubungan dan batasan karakteristik disesuaikan dengan 
keadaan yang ditemukan pada tiap-tiap partisipan. Topik yang diteliti yakni kemampuan mengontrol halusinasi dengar (Aji, 2019).

\subsubsection{Perencanaan Keperawatan}

Rencana tindakan Keperawatan Untuk Pasien. (Yusuf et al,2015)

1. Tujuan tindakan untuk pasien meliputi hal berikut.

a. Pasien mengenali halusinasi yang dialaminya.

b. Pasien dapat mengontrol halusinasinya.

c. Pasien mengikuti program pengobatan secara optimal.

2. Tindakan keperawatana.

a. Membantu pasien mengenali halusinasi dengan cara berdiskusi dengan pasien tentang isi halusinasi (apa yang didengar/dilihat), waktu terjadi halusinasi, frekuensi terjadinya halusinasi, situasi yang menyebabkan halusinasi muncul, dan respons pasien saat halusinasi muncul.

b. Melatih pasien mengontrol halusinasi. Untuk membantu pasien agar mampu mengontrol halusinasi, Anda dapat melatih pasien empat cara yang sudah terbukti dapat mengendalikan halusinasi, yaitu sebagai berikut.

1) Menghardik halusinasi.

2) Bercakap-cakap dengan orang lain.

3) Melakukan aktivitas yang terjadwal.

4) Menggunakan obat secara teratur.

Rencana tindakan keperawatan untuk keluarga.

1. Tujuan

a. Keluarga dapat terlibat dalam perawatan pasien baik di rumah sakit maupun di rumah.

b. Keluarga dapat menjadi sistem pendukung yang efektif untuk pasien.

2. Tindakan keperawatan 
a. Diskusikan masalah yang dihadapi keluarga dalam merawat pasien.

b. Berikan pendidikan kesehatan tentang pengertian halusinasi, jenis halusinasi yang dialami pasien, tanda dan gejala halusinasi, proses terjadinya halusinasi, serta cara merawat pasien halusinasi.

c. Berikan kesempatan kepada keluarga untuk memperagakan cara merawat pasien dengan halusinasi langsung di hadapan pasien.

d. Buat perencanaan pulang dengan keluarga.

\subsubsection{Implementasi}

Implementasi disesuaikan dengan rencana tindakan keperawatan. Pada situasi nyata sering pelaksanaan jauh berbeda dengan rencana, hal ini terjadi karena perawat belum terbiasa menggunakan rencana tertulis dalam melaksanakan tindakan keperawatan. Sebelum melaksanakan tindakan keperawatan yang sudah direncanakan, perawat perlu memvalidasi dengan singkat apakah rencana tindakan masih sesuai dan dibutuhkan klien sesuai dengan kondisinya (here and now). Perawat juga menilai diri sendiri, apakah kemampuan interpersonal, intelektual, tekhnikal sesuai dengan tindakan yang akan dilaksanakan, dinilai kembali apakah aman bagi klien. Setelah semuanya tidak ada hambatan maka tindakan keperawatan boleh dilaksanakan.

Adapun pelaksanaan tindakan keperawatan jiwa dilakukan berdasarkan Strategi Pelaksanaan (SP) yang sesuai dengan masingmasing masalah utama. Pada masalah gangguan sensori persepsi: halusinasi pendengaran, terdapat 2 jenis SP, yaitu SP Klien dan SP Keluarga.

SP klien terbagi menjadi SP 1 (membina hubungan saling percaya, mengidentifikasi halusinasi "jenis, isi, waktu, frekuensi, situasi, 
perasaan dan respon halusinasi", mengajarkan cara menghardik, memasukan cara menghardik ke dalam jadwal; SP 2 (mengevaluasi SP 1, mengajarkan cara minum obat secara teratur, memasukan ke dalam jadwal); SP 3 (mengevaluasi SP 1 dan SP 2, menganjurkan klien untuk mencari teman bicara); SP 4 (mengevaluasi SP 1, SP 2, dan SP 3, melakukan kegiatan terjadwal).

SP keluarga terbagi menjadi SP 1 (membina hubungan saling percaya, mendiskusikan masalah yang dihadapi keluarga dalam merawat pasien, menjelaskan pengertian, tanda dan gejala helusinasi, jenis halusinasi yang dialami klien beserta proses terjadinya, menjelaskan cara merawat pasien halusinasi); SP 2 (melatih keluarga mempraktekan cara merawat pasien dengan halusinasi, melatih keluarga melakukan cara merawat langsung kepada pasien halusinasi); SP 3 (membantu keluarga membuat jadwal aktivitas di rumah termasuk minum obat (discharge planing), menjelaskan follow up pasien setelah pulang).

Pada saat akan dilaksanakan tindakan keperawatan maka kontrak dengan klien dilaksanakan dengan menjelaskan apa yang akan dikerjakan dan peran serta klien yang diharapkan, dokumentasikan semua tindakan yang telah dilaksanakan serta respon klien.

\subsubsection{Evaluasi Keperawatan}

Evaluasi adalah proses hasil atau sumatif dilakukan dengan membandingkan respon klien pada tujuan umum dan tujuan khusus yang telah ditentukan.halusinasi pendengaran tidak terjadi perilaku kekerasan, klien dapat membina hubungan saling percaya, klien dapat mengenal halusinasinya, klien dapat mengontrol halusinasi dengar dari jangka waktu 4x24 jam didapatkan data subjektif keluarga menyatakan senang karena sudah diajarkan teknik mengontrol halusinasi, keluarga menyatakan pasien mampu melakukan beberapa 
teknik mengontrol halusinasi. Data objektif pasien tampak berbicara sendiri saat halusinasi itu datang, pasien dapat berbincang-bincang dengan orang lain, pasien mampu melakukan aktivitas terjadwal, dan minum obat secara teratur ( Aji, 2019 ) 


\section{BAB 3 \\ TINJAUAN KASUS}

\subsection{Identitas Klien}

Inisial

Tanggal Pengkajian

Umur

Agama

Informan
: Ny.S

: 17 Februari 2021

: 49 Tahun

: Budha

: Klien dan penjaga pasien di yayasan

\subsection{Alasan Masuk Rumah Sakit}

Klien suka menyendiri,melamun,mondar mandir, gelisah, mendengar suarasuara tanpa wujud.

\subsection{Faktor Predisposisi}

Klien pernah di rawat di RSJ lhoksemawe sebelumnya 6 tahun yang lalu di rawat hanya 4 hari . Di rumah klien tidak rutin minum. Semenjak di rumah Klien tidak pernah Kontrol ke RSJ ataupun klinik Jiwa, sehingga timbul gejala di atas, pasien mengosumsi obat yaitu :

Resperidon (2X1)

Clozapine $25 \mathrm{mg}(1 \mathrm{x} 1)$

\subsection{Fisik}

Tanda vital

TD : 110/90 mmHg, N : 96 x/I, S : $37{ }^{0} \mathrm{C}, \mathrm{P}: 20 \mathrm{x} / \mathrm{i}$

TB : $150 \mathrm{~cm}, \mathrm{BB}: 55 \mathrm{Kg}$

Klien tidak memiliki keluhan fisik.

\subsection{Psikososial}

\subsubsection{Genogram}



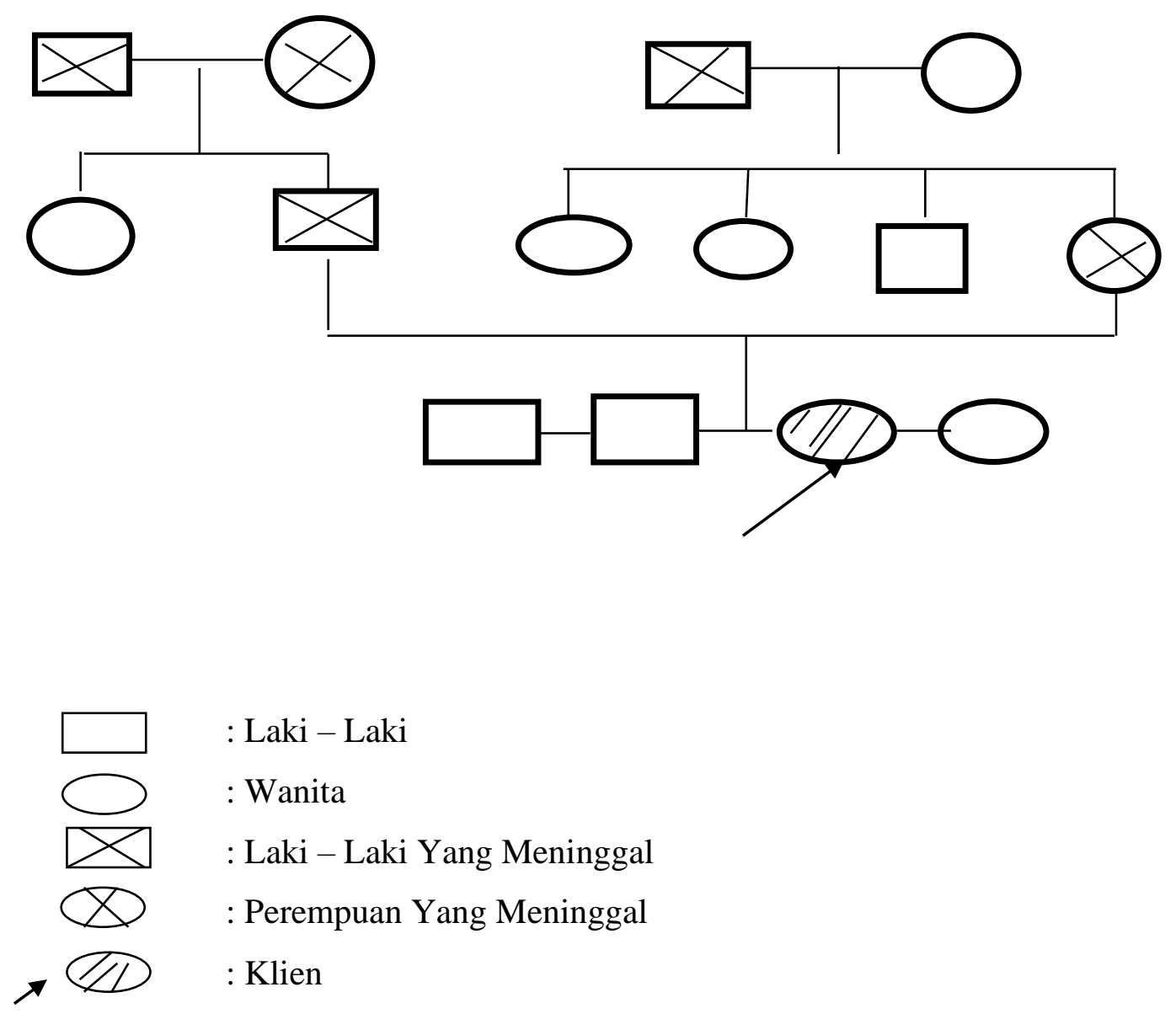

Berdasarkan genogram di atas, dapat dilihat bahwa klien merupakan anak ke 3 dari 4 bersaudara, tidak ada riwayat keluarga yang mengalami gangguan jiwa. Klien belum menikah.

\subsubsection{Konsep diri}

1. Gambaran diri : Klien menyukai keseluruhan bagian tubuhnya

2. Identitas Diri: Klien memiliki latar belakang pendidikan terakhir SMP, sebelum dirawat di RSJ klien pernah bekerja sebagai penjaga toko dan klien merasa senang dengan pekerjaannya.

3. Peran Diri : Klien sebagai sebagai anak, klien merasa tidak berguna karena tidak dapat membantu keluarga.

4. Ideal diri : Klien mengatakan malu bahwa dia memiliki gangguan jiwa dan tidak bekerja lagi, klien berharap segera sembuh dan 
bekerja kembali, klien sedih dan putus asa karena penyakitnya tak kunjung sembuh dan klien merasa tidak di pedulikan keluarga karena jarang di jenguk.

5. Harga diri : klien merasa tidak berguna karena dirawat diyayasan jiwa

Masalah keperawatan : Gangguan Konsep Diri : Harga diri rendah

\subsubsection{Hubungan Sosial}

1. Orang yang berarti :adik

2. Peran serta dalam kegiatan kelompok / masyarakat : Tidak berperan dalam kegiatan sosial

3. Hambatan dalam berhubungan dengan orang lain : klien mengatakan tidak berminat untuk terlalu banayak berkomunikasi dengan pasien yang lain

\subsubsection{Spiritual}

1. Nilai dan keyakinan : Klien menganut agam Budha dan pasien mempercayai adanya TUHAN.

2. Kegiatan ibadah : Klien selama dirawat sering beribadah . Masalah keperawatan: tidak ada Masalah keperawatan

\subsubsection{Status Mental}

1. Klien berpenampilan kurang rapi dan kurang bersih dalam berpakaian

2. Klien menjawab setiap pertanyaan dengan lambat sesuai dengan yang ditanyakan oleh perawat.

3. Klien mampu melakukan aktivitas sehari-hari seperti merapikan kamar, mencuci piring, dan mandi sendiri.

4. Klien merasa sedih dan putus asa karena tidak kunjung sembuh, merasa tidak berguna karena tidak dapat membantu keluarga, klien merasa malu karena di rawat di yayasan pemenang jiwa.

Masalah Keperawatan: Harga diri rendah 
5. Klien tidak Labil

6. Selama proses interaksi, klien cukup kooperatif serta kontak mata baik antara perawat-klien

7. Klien ketakutan saat mengalamihalusinasi pendengaran yaitumendengar suara-suara menyuruhnya untuk minum air putih Timbul pada saat sendiri dan terjadi pada sore hari.

Masalah Keperawatan : Gangguan Persepsi Sensori : Halusinasi pendengaran

8. Klien mengutarakan pendapat dengan baik

9. Klien menyampaikan isi pikir sesuai dengan pertanyaan

10. Klien dalam keadaan sadar (Composmentis) serta memiliki orientasi yang baik terkait orang, tempat, waktu.

11. Klien mampu mengingat hal-hal yang terjadi di masa lalu

12. Klien mampu fokus pada topik pembicaraan.

13. Klien mampu membedakan yang baik dan buruk dalam kegiatan seharihari

14. Daya tilik diri yakni klien menyadari bahwa dirinya mengalami gangguan jiwa halusinasi dan ingin segera sembuh.

\subsection{Kebutuhan Persiapan Pulang}

1. Klien mampu melakukan kegiatan makan dengan bantuan minimal, klien makan 3x dalam sehari.

2. Klien melakukan eliminasi BAB/BAK secara mandiri

3. Klien mandi $2 \mathrm{x}$ sehari secara mandiri

4. Klien berpakaian secara mandiri dan rapi

5. Klien memiliki pola tidur siang dimulai dari jam 14.00-16.00 WIB dan pada malam hari klien memiliki pola tidur jam 21.00-06.00 WIB. Kualitas tidur klien terganggu karena klien sering terbangun pada malam hari karena mimpi buruk. Klien kadang-kadang berdoa sebelum dan sesudah tidur.

6. Klien mengkonsumsi obat dibantu oleh perawat 
7. Klien masih memerlukan perawatan lanjutan dan perawatan pendukung untuk proses pemulihan klien

8. Klien menjaga kebersihan tempat tidur dan lingkungan sekitar, mencuci piring setelah makan secara mandiri dan menyapu lantai.

9. Klien tidak memiliki kegiatan di luar rumah karena klien dalam proses perawatan.

\subsection{Masalah Psikososial Dan Lingkungan}

Klien memiliki masalah dalam berhubungan dengan lingkungan karena stigma masyarakat terhadap dirinya yang dirawat di yayasan pemenang jiwa. Masalah Keperawatan:Isolasi Sosial

\subsection{Aspek Medik}

Diagnosa Medik : Skizofrenia Paranoid

Terapi Medik : Risperidon 2 mg $(2 \times 1)$

Clozapine 25 mg (1x1)

\subsection{Analisa Data}

\begin{tabular}{|ll|l|}
\hline Data & Masalah Keperawatan \\
\hline DS : & Pengurus yayasan mengatakan & Gangguan Persepsi Sensori : Halusinasi \\
bahwa klien sering berteriak & \\
- Klien sering mendengarkan & \\
suara-suara tampa wajah yang & \\
menyuruhnya untuk selalu minum & \\
air putih & \\
- Klien mengatakan suara - suara & \\
tersebut muncul 3 kali / hari, & \\
muncul pada saat klien sedang & \\
menyendiri & \\
- Klien merasa gelisah dan takut & \\
jika mendengar suara tersebut &
\end{tabular}




\begin{tabular}{|l|l|}
\hline Do : & \\
Klien sering marah - marah, & \\
mondar - mandir, bicara sendiri, & \\
bicara ngawur, sering senyum - & \\
senyum sendiri & Isolasi Sosial: Menarik Diri \\
\hline Ks : & \\
kegiatan di kelompok/masyarakat. & \\
Klien mengatakan mempunyai & \\
hambatan dalam berhubungan & \\
dengan orang lain karena klien sulit & \\
bergaul dan selalu ingin menyendiri. & \\
Do : \\
Klien tampak menghindari interaksi, \\
terlihat sedih, pendangan menunduk \\
kebawah
\end{tabular}

\subsection{Daftar Masalah Keperawatan}

1. Gangguan Persepsi Sensori : Halusinasi pendengaran

2. Isolasi sosial : Menarik diri

\subsection{Pohon Masalah}

Halusinasi Pendengaran

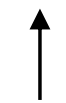

Isolasi Sosial : Menarik diri 


\subsection{Diagnosa Keperawatan}

1. Gangguan Persepsi Sensori : Halusinasi pendengaran

\subsection{Implementasi Keperawatan}

\begin{tabular}{|c|c|c|}
\hline WAKTU & Implemtasi & Evaluasi \\
\hline $\begin{array}{lr}17 & \text { Februari } \\
2010 & 10.00 \\
\text { WIB } & \\
\end{array}$ & $\begin{array}{l}\text { 1. Data } \\
\text { Tanda dan gejala :bicara sendiri, marah - marah } \\
\text { tampa sebab, memalingkan muka ke arah telingga, } \\
\text { ketakutan pada suatu yang tidak jelas, } \\
\text { 2.Diagnosa Keperawatan } \\
\text { Husinasi pendengaran } \\
\text { 3.Tindakan Keperawatan } \\
\text { Sp1 halusinasi } \\
\text { - Melatih pasien } \\
\text { halusinasinya; isi, frekuensi, watu terjadi, } \\
\text { sruasi pencetus, perasaan dan respon } \\
\text { halusinasi } \\
\text { Mengontrol halusinasi dengan cara } \\
\text { menghardik }\end{array}$ & $\begin{array}{l}\text { - Pasien mampu mengenali halusinasi yang dialami } \\
\text { nya; isi, frekuensi, watu terjadi, sruasi } \\
\text { pencetus,perasaan, respon dengan mandiri } \\
\text { - } \begin{array}{l}\text { Pasien mampu Mengontrol halusinasinya dengan } \\
\text { cara menghardik dengan bantuan }\end{array} \\
\text { A : } \text { Halusinasi (+) } \\
\text { P : } \\
\text { - Latihan mengidentifikasi } \\
\text { frekuensi, watu terjadi, sruasi pencetus, perasaan dan } \\
\text { respon halusinasi } 3 x / \text { hari } \\
\text { - Latihan menghardik halusinasi } 3 x / \text { hari }\end{array}$ \\
\hline
\end{tabular}




\begin{tabular}{|l|l|l|}
\hline S.RTL & \\
Sp2; mengontrol halusinasi dengan cara minum obat & \\
Sp3; mengontrol halusinasi dengan cara bercakap - & \\
cakap & & \\
& & \\
& & \\
\end{tabular}




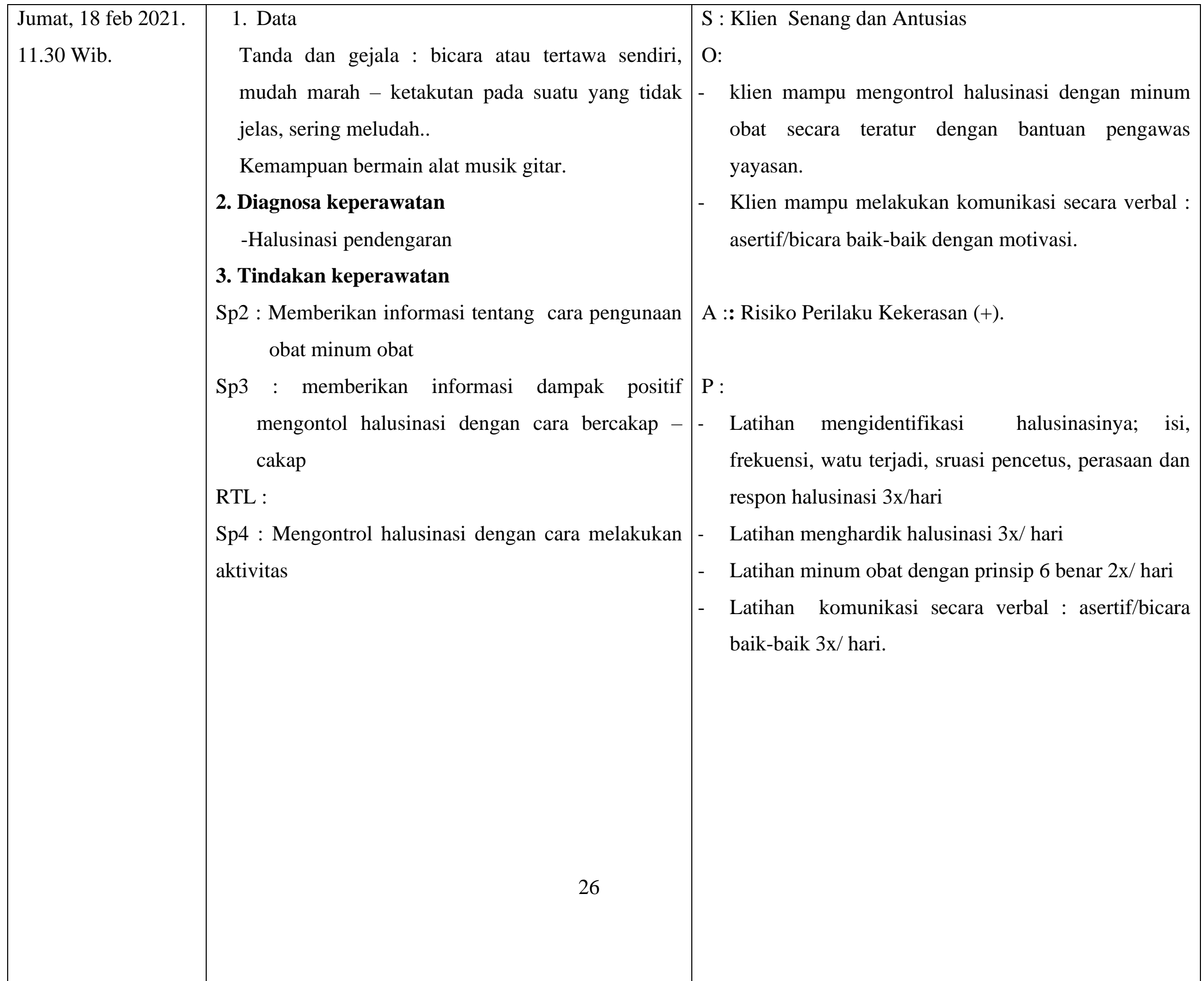




\begin{tabular}{|c|c|c|}
\hline $\begin{array}{l}\text { Sabtu, } 19 \text { feb } 2021 . \\
10.00 \text { Wib. }\end{array}$ & $\begin{array}{l}\text { 1. Data } \\
\text { Tanda dan gejala : bicara atau tertawa sendiri, } \\
\text { mudah marah - ketakutan pada suatu yang tidak } \\
\text { jelas, sering meludah.. } \\
\text { Kemampuan: bermain alat musik gitar. } \\
\text { 2. Diagnosa keperawatan } \\
\text { usinasi } \\
\text { 3. Tindakan keperawatan } \\
\text { : Halusinasi } \\
\text { - Mengevaluasi } \\
\quad \text { Halusinasi } \\
\text { - Melatih pasien untuk melakukan kegiatan } \\
\text { spritual dengan cara berdoa. } \\
\text { - } \\
\text { RTL : }\end{array}$ & $\begin{array}{l}\text { S: klien mengatakan dia merasa senang bisa bercakap- } \\
\text { cakap dengan orang lain } \\
\text { O : Klien mempraktekkan cara bercakap-cakap dengan } \\
\text { orang lain } \\
\text { A : Halusinasi pendengaran (+) } \\
\text { P : Intervensi dilanjutkan } \\
\text { - Latihan menghardik halusinasi } 3 \mathrm{x} / \text { hari } \\
\text { - Latihan minum obat dengan prinsip } 6 \text { benar } 2 \mathrm{x} / \\
\quad \text { hari } \\
\text { - Latihan bercakap-cakap dengan orang lain } 3 \mathrm{x} / \text { hari } \\
\text { - Latihan kegiatan spritual }\end{array}$ \\
\hline
\end{tabular}




\section{BAB 4 \\ PEMBAHASAN}

Setelah penulis melaksanakan asuhan keperawat kepada Ny.S dengan gangguan sensori persepsi: halusinasi pendengaran di Yayasan Pemenang Jiwa maka penulis pada $\mathrm{BAB}$ ini akan membahasan kesenjangan antara teoritis dengan tinjauan kasus.

Pembahasan dimulai melalui tahapan proses keperawatan yaitu pengkajian, diagnosa keparawatan, perencanaan, pelaksanaan dan evaluasi.

\subsection{Pengkajian}

Pada pembahasan ini diuraikan tentang hasil pelaksanaan tindakan keperawatan dengan pemberian terapi generalis pada klien halusinasi pendengaran. Pembahasan menyangkut analisis hasil penerapan terapi generalis terhadap masalah keperawatan halusinasi pendengaran. Tindakan keperawatan didasarkan pada pengkajian dan diagnosis keperawatan yang terdiri dari tindakan generalis yang dijabarkan sebagai berikut.

Tahap pengkajian pada klien halusinasi dilakukan interaksi perawat-klien melalui komunikasi terapeutik untuk mengumpulkan data dan informasi tentang status kesehatan klien. Pada tahap ini terjadi proses interaksi manusia, komunikasi, transaksi dengan peran yang ada pada perawat sebagaimana konsep Peplau tentang manusia yang bisa dipengaruhi dengan adanya proses interpersonal.

Selama pengkajian dilakukan pengumpulan data dari beberapa sumber, yaitu dari pasien dan tenaga kesehatan di ruangan. Penulis mendapat sedikit kesulitan dalam menyimpulkan data karena keluarga pasien jarang mengunjungi pasien di yayasan. Maka penulis melakukan pendekatan kepada pasien melalui komunikasi terapeutik yang lebih terbuka membantu pasien 
untuk memecahkan perasaannya dan juga melakukan observasi kepada pasien.

Adapun upaya tersebut yaitu:

1. Melakukan pendekatan dan membina hubungan saling percaya diri pada klien agar klien lebih terbuka dan lebih percaya dengan menggunakan perasaan.

2. Mengadakan pengkajian klien dengan wawancara

3. Mengadakan pengkajian dengan cara berbicara dengan pasien dan petugas yayasan.

Dalam pengkajian ini, penulis tidak menemukan kesenjangan karena ditemukan hal sama seperti pada tinjauan teoritis. Pada kasus Ny.S, mendengar suara-suara yang tidak jelas yang menggunya sehingga meresahkan orang lain, timbul pada saat sendiri atau melamun dan tidak menentu, timbul $3 \mathrm{kali} / \mathrm{hari}$, gelisah bila melihat halusinasi tersebut,menumpahkan air , Bicara sendiri, sulit tidur, muka tegang. Gejala gejala tersebut merupakan manifestasi klinis dari halusnasi (Keliat, dkk.2014). Selain itu terdapat faktor predisposisi maupun presipitasi yang menyebabkan kekambuhan penyakit yang dialami oleh Ny.S.

Tindakan keperawatan terapi generalis yang dilakukan pada Ny.S adalah strategi pertemuan pertama sampai pertemuan ketiga. Strategi pertemuan pertama meliputi mengidentifikasi isi, frekuensi, jenis, dan respon klien terhadap halusinasi serta melatih cara menghardik halusinasani dan melatih pasien untuk minum obat secara teratur. Strategi pertemuan kedua yang dilakukan pada Ny.S meliputi melatih cara mengendalikan dengan bercakapcakap kepada orang lain, menyusun jadwal kegiatan bersama-sama dengan klien.

\subsection{Diagnosa Keperawatan}

Pada Teori Halusinasi (NANDA, 2015-2017), diagnosa keperawatan yang muncul sebanyak 2 diagnosa keperawatan yang meliputi:

1. Halusinasi Pendengaran

2. Risiko perilaku kekerasan 
Sedangkan pada kasus Ny.S ditemukan dua diagnosa keperawatan yang muncul yang meliputi:, halusinasi, resiko perilaku kekerasan. Dari hal tersebut di atas dapat dilihat terjadi kesenjangan antara teori dan kasus. Dimana semua diagnosa pada teori muncul pada kasus Ny.S

\subsection{Implementasi}

Pada tahap implementasi, penulis hanya mengatasi 1 masalah keperawatan yakni: diagnosa keperawatan halusinasi pendengaran. Pada diagnosa keperawatan gangguan persepsi sensori halusinasi pendengaran dilakukan strategi pertemuan yaitu mengidentifikasi isi, frekuensi, waktu terjadi, perasaan, respon halusinasi. Kemudian strategi pertemuan yang dilakukan yaitu latihan mengontrol halusinasi dengan cara menghardik dan anjurkan minum obat secara teratur, strategi pertemuan yang ke dua yaitu latihan dengan cara bercakap-cakap pada saat aktivitas dan melatih klien melakukan semua jadwal kegiatan. Untuk melakukan implementsi pada keluarga, pada tahap-tahap diagnosa tidak dapat dilaksanakan karena penulis tidak pernah berjumpa dengan keluarga klien (keluarga tidak pernah berkunjung).

\subsection{Evaluasi}

Pada tinajauan teoritis evaluasi yang diharapkan adalah: Pasien mempercayai perawat sebagai terapis, pasien menyadari bahwa yang dialaminya tidak ada objeknya, dapat mengidentifikaasi halusinasi, dapat mengendalikan halusinasi melalui mengahrdik, latihan bercakap-cakap, melakukan aktivitas serta menggunakan obat secara teratur.

Pada tinjauan kasus evaluasi yang didapatkan adalah: Klien mampu mengontrol dan mengidentifikasi halusinasi, Klien mampu melakukan latihan bercakap-cakap dengan orang lain, Klien mampu melaksanakan jadwal yang telah dibuat bersama, Selain itu, dapat dilihat dari setiap evalusi yang dilakukan pada asuhan keperawatan, dimana terjadi penurunan gejala yang dialami oleh Ny.S dari hari kehari selama proses interaksi seperti suara 
halusinasi yang menyruhnya minum sebelem pemberian Sp timbul minimal 3 kali perhari setelah pemberian Sp halusinasi yang timbul hanya satu kali atau 2 kali perhari saja . 


\section{BAB 5 \\ PENUTUP}

\subsection{Kesimpulan}

Berdasarkan uraian pada pembahasan di atas, maka penulis dapat disimpulkan bahwa:

1. Pengkajian dilakukan secara langsung pada klien dan juga dengan menjadikan status klien sebagai sumber informasi yang dapat mendukung data-data pengkajian. Selama proses pengkajian, perawat mengunakan komunikasi terapeutik serta membina hubungan saling percaya antara perawat-klien. Pada kasus Ny.S, diperoleh bahwa klien mengalami gejala-gejala halusinasi seperti Mendengar suara-suara menyuruh dia minum, timbul pada saat sendiri atau melamun dan tidak menentu, timbul minimal 3kali/hari. Gelisah bila halusinasi tersebut datang,, sulit tidur, muka tegang,tidak mampu mempertahankan kontak mata.Faktor predisposisi pada Ny.S yaitu pernah mengalami gangguan jiwa sebelumnya.

2. Diagnosa keperawatan yang muncul pada kasus Ny.S sebanyak: Halusinasi pendengaran dan perilaku kekerasan. Tetapi pada pelaksanaannya, penulis fokus pada masalah utama yaitu halusinasi pendengaran.

3. Perencanaan dan implementasi keperawatan disesuaikan dengan strategi pertemuan pada pasien halusinasi pendengaran.

4. Evaluasi dperoleh bahwa terjadi peningkatan kemampuan klien dalam mengendalikan halusinasi yang dialami serta dampak pada penurunan gejala halusinasi pendengaran yang dialami.

\subsection{Saran}

1. Bagi Perawat

Diharapkan dapat meenrapkan komunikasi terapeutik dalam pelaksanaan strategi pertemuan 1-4 pada klien dengan halusinasi sehingga dapat mempercepat proses pemulihan klien.

2. Bagi Institusi Pendidikan 
Dapat meningkatkan bimbingan klinik kepada mahasiswa profesi ners sehingga mahasiswa semakin ampu dalam elakukan asuhan keperawatan pada pasien-pasien yang mengalami halusinasi pendengaran

3. Bagi Rumah Sakit

Laporan ini diharapkan dapat menjadai acuan dan referensi dalam memberikan asuhan keperawatan pada klien dengan halusinasi pendengaran. 


\section{DAFTAR PUSTAKA}

1. Aji, W. M. H. (2019). Asuhan Keperawatan Orang Dengan Gangguan Jiwa Halusinasi Dengar Dalam Mengontrol Halusinasi. https://doi.org/10.31219/osf.io/n9dgs

2. Azizah.L.M., Zainuri. I., \& Akbar.A. (2016). Buku Ajar Keperawatan Kesehatan Jiwa. Yogyakarta: Indomedia Pustaka.

3. Halawa. A. (2015). Pengaruh Terapi Aktivitas Kelompok: Stimulasi Persepsi Sesi 1-2 Terhadap Kemampuan Mengontrol Halusinasi Pendengaran Pada Pasienskizofrenia Di Ruang Flamboyan Rumah Sakit Jiwamenur Surabaya. Jurnal Keperawatan, 4(1), 30-37. https://doi.org/10.47560/kep.v4i1.185

4. Hafiszudiin. (2021). Asuhan Keperawatan Jiwa Pada Tn.A Dengan Masalah Halusinasi Pendengaran. https://doi.org/10.31219/osf.io/9xn25

5. Keliat, B.A \& Akemat. 2014. Model Praktik Keperawatan Profesional Jiwa. Jakarta EGC

6. Muhith, A.(2015)Pendidikan keperawatan jiwa: Teori dan aplikasi. Penerbit Andi.

7. Oktiviani, D. P. (2020). Asuhan Keperawatan Jiwa Pada Tn. K dengan masalah Gangguan Persepsi Sensori: Halusinasi Pendengaran di Ruang Rokan Rumah Sakit Jiwa Tampan (Doctoral dissertation, Poltekkes Kemenkes Riau).http://repository.pkr.ac.id/id/eprint/498

8. Pardede, J. A., \& Hasibuan, E. K. (2019). Dukungan Caregiver Dengan Frekuensi Kekambuhan Pasien Skizofrenia. Idea Nursing Journal, 10(2). http://e-repository.unsyiah.ac.id/INJ/article/view/17161

9. Pardede, J. A., \& Laia, B.(2020). Decreasing Symptoms of Risk of Violent Behavior in Schizophrenia Patients Through Group Activity Therapy.Jurnal Ilmu Keperawatan Jiwa, 3(3), 291-300. http://dx.doi.org/10.32584/jikj.v3i3.621

10. Pardede, J.A,. (2020). Family Knowledge about Hallucination Related to Drinking Medication Adherence on Schizophrenia Patient. Jurnal Penelitian PerawatProfesional, 2(4),399-408. https://doi.org/10.37287/jppp.v2i4.183

11. Sutinah. S., Harkomah. I., \& Saswanti. N. (2020). Terapi Aktivitas Kelompok Stimulasi Persepsi Sensori (Halusinasi) Pada Klien Halusinasi Di Rumah Sakit Jiwa Provinsi Jambi. Jurnal Pengabdian Masyarakat Dalam Kesehatan. 2(2).https://e-journal.unair.ac.id/JPMK 
12. Yusuf. A.,Fitriasari.R., \& Nihayati. H.A.(2015). Buku Ajar Keperawatan Kesehatan Jiwa. Jakarta : Salemba Medika. 